\title{
Incorporation of Strontium up to 5 Mol. (\%) to Hydroxyapatite did not Affect its Cytocompatibility
}

\author{
Débora dos Santos Tavares ${ }^{a *}$, Cristiane Xavier Resendea , Maíra Paiva Quitan", \\ Letícia de Oliveira Castro $^{\mathrm{b}}$, José Mauro Granjeiro ${ }^{\mathrm{b}, \mathrm{c}}$, Gloria de Almeida Soares ${ }^{\mathrm{a}}$ \\ ${ }^{a}$ Materials Engineering Department, COPPE, Rio de Janeiro Federal University - UFRJ, \\ CP 68505, CEP 21941-972, Rio de Janeiro, RJ, Brazil \\ ${ }^{b}$ Cell and Molecular Biology Department and Cell Therapy Center UPC-HUAP, \\ Fluminense Federal University - UFF, Outeiro de S. J. Batista, s/n, CP 24150, Niterói, RJ, Brazil \\ ${ }^{c}$ Dipro/Bioengineering, INMETRO, Av. Nossa Senhora das Graças, $n^{\circ} 50$, \\ CEP 25250-020, Xerém, Duque de Caxias, RJ, Brazil
}

Received: November 9, 2010; Revised: July 29, 2011

\begin{abstract}
The aim of this work was to produce hydroxyapatite (HA) granules containing 0, 0.5, 1 and 5 mol. (\%) of strontium ( $\mathrm{Sr}$ ), evaluate the physico-chemical properties and also the cytotoxicity by three different parameters of cell viability (ISO 10993-5, 10993-12). The physico-chemical characterization was carried out by using X-ray diffraction (XRD), Fourier-transform infrared spectroscopy (FTIR) and X-ray fluorescence (XRF). The XRD profile presented the main peaks of HA (JCPDS 860740) and the absorption bands of HA were identified by FTIR. The XRF results showed that the strontium concentration was close to the theoretical value. Regarding the cytotoxicity assays, the incorporation of strontium up to $5 \mathrm{~mol}$. (\%) to the HA did not affected dehydrogenase activity (XTT, 2,3-bis[2-methyloxy-4-nitro-5-sulfophenyl]-2H-tetrazolium-5-carboxanilide), membrane integrity (neutral red uptake) or DNA contend (incorporation of crystal violet), in relation to HA alone. In conclusion, hydroxyapatite containing from 0.5 to $5 \mathrm{~mol}$. (\%) of Sr was successfully produced and presented no cytotoxicity.
\end{abstract}

Keywords: strontium, hydroxyapatite, cytotoxicity

\section{Introduction}

Bone loss due to chronic diseases or trauma can result in large defects, which challenge clinicians, and most of the time bone grafts are needed. Research is being conducted in order to improve bone formation through the implantation of biomaterials with a superior bioactivity. Calcium phosphate ceramics, such as hydroxypapatite (HA), are widely used as bone grafts because of their similarity to the mineral phase of the bone. Moreover, they seem to induce the formation of a biological apatite layer, and are thus considered bioactive materials ${ }^{1,2}$. Biological apatite is a calcium-deficient apatite with several substitutions in its crystal lattice, such as $\mathrm{F}^{-}, \mathrm{Cl}^{-}, \mathrm{Na}^{+}$, $\mathrm{K}^{+}, \mathrm{Fe}^{2+}, \mathrm{Zn}^{2+}, \mathrm{Sr}^{2+}, \mathrm{Mg}^{2+}$, and $\mathrm{CO}_{3}^{-2}{ }^{[3,4,5]}$. Granular material is often used for bone filling in order to avoid phagocytosis, since it has been shown that particle size influences the induction of bone resorption ${ }^{6}$.

Strontium ( $\mathrm{Sr}$ ) is a bone-seeking trace element and $98 \%$ of its total content is in the skeleton ${ }^{7}$. It was reported that low dosages can improve bone formation while high dosages induce defective bone mineralization ${ }^{8,9}$. Recent in vitro studies showed that strontium ranelate, a novel agent used in osteoporosis (characterized by low bone mass and susceptibility to fractures) treatment, inhibits bone resorption via the osteoclasts and promotes osteoblast replication and bone formation ${ }^{10}$. In vivo tests with strontium-substituted hydroxyapatite $(\mathrm{Sr} / \mathrm{Ca}=0.10)$ cement were performed using a rabbit hip replacement model and an apatite layer was found six months later between the cement and the cancellous bone ${ }^{11}$. As reported, strontiumcontaining hydroxyapatite (Sr-HA) appears to be an interesting bone substitute material. Because of the difference in the atomic radius between strontium and calcium, the crystal lattice becomes distorted and therefore the Sr-HA stability decreases, facilitating its replacement by new bone ${ }^{12}$.
In vitro studies of Sr-HA containing 0, 1, 5, 10 and 100 mol. (\%) Sr presented good biocompatibility, but the cytotoxicity increased as the strontium concentration increased ${ }^{13}$. Moreover, osteoblast-like MG63 cells cultured on Sr-HA nanocrystals containing 0, 1, 3, 7 atom. (\%) exhibited good proliferation and increased values of the differentiation parameters ${ }^{14}$. Differences in the responses of biomaterials have been reported depending on the cytotoxicity test used. Therefore, it is important to evaluate this response by using a combination of more than one parameter related to cell functions in order to increase the reliability of results ${ }^{15}$.

Previous works indicated that even Sr-HA with 100 mol. (\%) of strontium has a good biocompatibility, but which also showed that cytotoxicity increased proportionally to the strontium content. Due to the ambiguous results in the literature, the aim of this study was to produce dense HA granules containing $0,0.5,1$ and 5 mol. (\%) of strontium (which is closer to the biological content in HA), evaluate the physico-chemical properties and also the cytotoxicity of produced biomaterials by three different parameters of cell viability, according to ISO $10993-5^{[16]}$ and $10993-12^{[17]}$ standards.

\section{Materials and Methods}

\subsection{Synthesis of HA and processing the dense granules}

Strontium-substituted hydroxyapatites were synthesized by a wet chemical route. $\mathrm{A} \mathrm{KH}_{2} \mathrm{PO}_{4}$ solution (MERCK, 99.5 wt. (\%) pure) was prepared and dropped into the $\mathrm{Ca}\left(\mathrm{NO}_{3}\right)_{2}$ (VETEC, 99 wt. (\%) pure) and $\mathrm{Sr}\left(\mathrm{NO}_{3}\right)_{2}(\mathrm{MERCK}, 99 \mathrm{wt}$. (\%) pure) solution over a period of about 2-3 hours, with constant heating at $40{ }^{\circ} \mathrm{C}$ and stirring. The 
$\mathrm{pH}$ of the solution was adjusted to 11 using an aqueous solution of ammonium $50 \%(\mathrm{v} / \mathrm{v})$, with a final concentration of $12.5 \%$. The reaction product was kept in suspension by constant stirring and heating to $40{ }^{\circ} \mathrm{C}$ for 2 hours. The precipitate was centrifuged and washed several times with ultra-pure water until $\mathrm{pH} 7$ was reached. Finally, the precipitate was dried for 24 hours at $37^{\circ} \mathrm{C}$. The dried powder was crushed and sieved using a $125 \mu \mathrm{m}$ sieve to obtain the fine fractions. All materials were uniaxially pressed into cylindrical tablets under a compressive strength of $216 \mathrm{MPa}$, followed by sintering at $1150{ }^{\circ} \mathrm{C}$ for 4 hours in air $\left(2.8^{\circ} \mathrm{C} /\right.$ min heating rate $)$. The tablets were crushed and sieved to select dense granules in the range of 300-600 $\mu \mathrm{m}$.

$\mathrm{The} \mathrm{Ca}+\mathrm{Sr} / \mathrm{P}$ molar ratio was equal to 1.5 according to the apatite chemical formula of $\mathrm{Ca}_{9-\mathrm{x}} \mathrm{Sr}_{x}\left(\mathrm{PO}_{4}\right)_{6}(\mathrm{OH})_{2}$ in order to produce non-stoichiometric apatites, which are usually more soluble than the stoichiometric ones. Table 1 gives the concentrations used for each apatite composition.

\subsection{Physico-chemical characterization}

The calcium phosphate phase of the granular material was determined using an X-ray diffractometer (SHIMADZU XRD 6000) with monochromatized $\mathrm{Cu} \mathrm{k} \alpha$ radiation and an operational tube with a voltage and current of $40 \mathrm{kV}$ and $30 \mathrm{~mA}$, respectively. The angle of diffraction was from 10 to $60^{\circ}$ and the granular material was crushed. The resulting trace was analyzed and compared with the standard library of known diffraction patterns. The granules (mixed with $\mathrm{KBr}$ ) were also examined by FTIR in order to identify the vibrational modes of the molecules (Perkin Elmer, Spectrum 100) in the range of $500-4000 \mathrm{~cm}^{-1}$. At least 16 scans were conducted and the average of the results was reported. The chemical composition of the samples was determined by X-ray fluorescence (XRF) on RIGAKU RIX 3100 equipment with a rhodium tube $(4 \mathrm{~kW})$. Therefore, the strontium content and also the $\mathrm{Ca}+\mathrm{Sr} / \mathrm{P}$ ratio could be verified.

\subsection{Cytotoxicity test}

Samples were extracted in a culture medium $\left(100 \mathrm{mg} \cdot \mathrm{mL}^{-1}\right.$, apatite granules/DMEM free of bovine fetal serum) at $37{ }^{\circ} \mathrm{C}$ for 24 hours and the extracts were collected for the cytotoxicity assay according to ISO 10993-5 $5^{[16]}$ and 10993-12 $2^{[17]}$. As control were used $1 \%$ phenol solution (positive) and titanium powder (100 mg. $\mathrm{mL}^{-1}$, as a negative control). MC3T3 osteoblasts (CRL 2594 - ATCC) were seeded into a 96-well cell culture plate $\left(1 \times 10^{4}\right.$. well $\left.{ }^{-1}\right)$ and cultured in DMEM containing $\mathrm{NaHCO}_{3}\left(1.2\right.$ g.L $\left.\mathrm{L}^{-1}\right)$, ampicillin $\left(0.025\right.$ g.L $\left.\mathrm{L}^{-1}\right)$, and streptomycin $\left(0.1\right.$ g. $\left.\mathrm{L}^{-1}\right)$ supplemented with $10 \%$ bovine fetal serum for 24 hours at $37^{\circ} \mathrm{C}$ under $5 \% \mathrm{CO}_{2} / 95 \%$ air conditions. Afterwards, the medium was replaced by each extract and supplemented with $10 \%$ bovine fetal serum (BFS) and maintained at $37{ }^{\circ} \mathrm{C}$ under $5 \%$ $\mathrm{CO}_{2} / 95 \%$ air conditions.

After 24 hours of cell exposure to each extract media, cytotoxicity was evaluated using a commercial kit (Cytotox, Xenometrix, Germany) which allows the use of three different parameters of cell survival and integrity on the same sample: 2,3-bis[2-methyloxy4-nitro-5-sulfophenyl]-2H-tetrazolium-5-carboxanilide (XTT), neutral red (NR) and crystal violet dye elution (CVDE). The XTT cell proliferation assay is based on the ability of mitochondrial dehydrogenase enzymes to convert the yellow water-soluble tetrazolium salt XTT into orange colored soluble compounds of formazan, measured by their absorbance at $480 \mathrm{~nm}^{18}$. Neutral red is a survival/viability test based on the ability of living cells to incorporate the neutral red dye in their lysosomes, where it accumulates on membrane-intact cells ${ }^{19}$; the quantity of dye incorporated can be measured at $540 \mathrm{~nm}$. The CVDE assay evaluates cell density by staining DNA; the absorbance at $540 \mathrm{~nm}$ is proportional to the amount of cells in each well ${ }^{20}$. The absorbance data were obtained with a microplate UV/Vis spectrophotometer (PowerWave MS2, BioTek Instruments, USA).

All of the tests were performed in quintuplicate. Mean values and standard deviations were submitted to one-way analysis of variance (ANOVA) and Tukey's post-test considering significant differences if $\mathrm{p}<0.05$.

\section{Results and Discussion}

The chemical compositions of the powders obtained from the X-ray fluorescence are shown in Table 2. Regarding the X-ray fluorescence results, the strontium concentration incorporated in the HA was very close to the theoretical value (Table 1). Moreover, the $(\mathrm{Ca}+\mathrm{Sr}) / \mathrm{P}$ in all of the substituted $\mathrm{HA}$ was close to 1.5 , and these results are comparable to the $\mathrm{Ca} / \mathrm{P}$ ratio in pure $\mathrm{HA}, 1.53$, corresponding to a calcium-deficient apatite.

Figure 1 shows the XRD patterns of hydroxyapatite with the different $\mathrm{Sr} / \mathrm{Ca}$ molar ratios after sintering. All of the patterns show the mean peaks of hydroxyapatite at 25.8, 31.8, 32.3 and $32.9^{\circ}$ (JCPDS 860740), compatible with a Sr-HA solid solution, since the crystalline structure of HA was maintained and no other phase containing strontium was formed after the calcium partial substitution by strontium ${ }^{21}$, according to XRD data showed in Figure 1. The XRD of $0,0.5$, and 1 mol. (\%) Sr-HA granules exhibited a peak at $31.2^{\circ}$, which is typical of $\beta$-TCP and a decreased in its intensity was noted with the augmentation of strontium content. The presence of $\beta$-TCP is, probably, a consequence of the transformation of HA to TCP that occurs in calcium-deficient apatites. A previous report had already described the presence of TCP in Sr-HA, and its formation was attributed to the non-stoichiometry of the apatite structure causing structural and compositional changes in elevate temperatures ${ }^{22}$. Structural changes to TCP upon calcining calcium deficient HA at temperatures between 500 and $1100{ }^{\circ} \mathrm{C}$ (up to $1450{ }^{\circ} \mathrm{C}$ ) were also reported earlier $^{23}$. Furthermore, other undesirable phases can be found as reported by Dagang et al. ${ }^{24}$ during the synthesis of Sr-HA. One of the most critical parameters in determining properties and thermal stabilities of $\mathrm{HA}$ powder is the $\mathrm{Ca} / \mathrm{P}$ ratio ${ }^{25}$. Accordingly, the $\beta$-TCP peak was not observed in 5\% Sr-HA samples probably due to its $\mathrm{Ca}+\mathrm{Sr} / \mathrm{P}$ molar ratio, which was higher when compared to the

Table 1. Molar concentrations used for the powder synthesis of $\mathrm{Ca}_{9-\mathrm{x}} \mathrm{Sr}_{\mathrm{x}}\left(\mathrm{PO}_{4}\right)_{6}(\mathrm{OH})_{2}$, where $\mathrm{x}=0.0,0.5,1.0$ and 5.0.

\begin{tabular}{cccc}
\hline $\mathrm{Sr}(\mathrm{x})$ & $\mathrm{KH}_{2} \mathrm{PO}_{4}$ & $\mathrm{Ca}(\mathrm{NO})_{2}$ & $\mathrm{Sr}\left(\mathrm{NO}_{3}\right)_{2}$ \\
\hline 0.0 & 0.80 & 0.91 & 0.000 \\
0.5 & 0.80 & 0.90 & 0.009 \\
1.0 & 0.80 & 0.90 & 0.018 \\
5.0 & 0.80 & 0.86 & 0.090 \\
\hline
\end{tabular}

Table 2. XRF analysis ${ }^{1}$ of granular material showing $(\mathrm{Ca}+\mathrm{Sr}) / \mathrm{P}$ and $\mathrm{Sr} / \mathrm{Ca}$ ratios.

\begin{tabular}{ccc}
\hline Samples & $(\mathrm{Ca}+\mathrm{Sr}) / \mathrm{P}$ & $\mathrm{Sr} / \mathrm{Ca}(\%)$ \\
\hline HA & 1.53 & 0 \\
$0.5 \%$ Sr-HA & 1.48 & 0.55 \\
$1.0 \%$ Sr-HA & 1.50 & 1.0 \\
$5.0 \%$ Sr-HA & 1.55 & 5.0 \\
\hline
\end{tabular}

${ }^{1}$ The data represent one analysis of the sample. 
other apatites synthesized herein (Table 2). In addition, the partial replacement of $\mathrm{Ca}^{2+}$ by $\mathrm{Sr}^{2+}$ increases the solubility of HA. This phenomenon was studied by Christoffersen et al. ${ }^{26}$, who reported that the solubility of apatite increases with an increasing strontium content.

The FTIR spectra of HA and Sr-doped HA are shown in Figure 2 and different modes of molecular vibration characteristics of the apatites can be observed. The bands at 1091 (v3), 1049 (v3), $967(\mathrm{v} 3), 598(\mathrm{v} 4)$ and $568 \mathrm{~cm}^{-1}(\mathrm{v} 4)$ are typical of phosphate $\left(\mathrm{PO}_{4}^{-3}\right)$ molecular vibration and were present in all of the spectra from the synthetic apatites. The sharp band at 3572 and $632 \mathrm{~cm}^{-1}$ corresponds to the $\mathrm{OH}^{-}$stretching mode, characteristic of HA. A well-defined band of carbonate, at $1385 \mathrm{~cm}^{-1}$, was detected when the strontium concentration was equal or superior to $1 \% \mathrm{Sr}$. The band present in this region suggests that phosphate ions are partially substituted by carbonate. This carbonate substitution may be due to the reactive absorption of atmospheric carbon dioxide by the alkaline solution during the slurry preparation and reaction. A similar carbonate absorption band in the region of $1367-1527 \mathrm{~cm}^{-1}$ was previously reported on $\mathrm{Sr}-\mathrm{HA}^{27}$, which increased of intensity with strontium content. Another study showed that carbonate incorporation decreases the crystallinity of the apatites and enhances solubility ${ }^{28}$.

Cytotoxicity assays provide a measure of cell death caused by contact with materials or their extracts, and only one test is not capable of detecting the cytotoxicity of biomaterials ${ }^{29,30}$. Hence, membrane integrity (NR), metabolic activity (XTT) and cell density (CVDE) were evaluated. Figure 3 shows the in vitro cytotoxicity measured by XTT, NR, and CVDE after 24 hours in culture with the apatite (partially substituted with $\mathrm{Sr}$ and pure HA) extracts.

The XTT analysis showed no significant difference among the Sr-HA or HA extracts or cells exposed only to DMEM plus BFS. Metabolic activity was around 1.5 fold greater in the Sr-HA groups, irrespective to Sr concentration, in relation to cells in DMEM alone $(p<0.05)$. As expected, the positive control $(1 \%$ phenol $)$ significantly decreased cell viability.

A similar trend was presented by Fu et al. ${ }^{13}$ when the strontium concentration was up to $5 \%$, using the same assay. Capuccini et al. ${ }^{31}$ showed that the presence of strontium significantly improved osteoblast adhesion in early culture phases. Moreover, cell adhesion increased with increasing strontium content $(1,5$, and $10 \mathrm{Sr}$ at. \%). The cytotoxicity of Sr-HA containing 1, 5, 10, and $100 \mathrm{~mol}$. (\%) was also evaluated by Yuan-Fei et al. ${ }^{32}$ via methyltetrazolium (MTT) assay and showed that all of the bioceramics studied had good biocompatibility. Furthermore, osteoblast-like MG63 cells cultured on the Sr-HA nanocrystals containing $0,1,3$, and 7 atom. (\%) displayed good proliferation and increased values of the differentiation parameters ${ }^{14}$. Osteoprecursor cell behavior was examined through MTT reduction at 3, 7, and 14 days of incubation by culturing them onto $10 \mathrm{~mol} \%$ $\mathrm{Sr}-\mathrm{HA}$ surface. The authors concluded that $\mathrm{Sr}-\mathrm{HA}$ induced better cell attachment and proliferation when compared to $\mathrm{HA}^{33}$.

Regarding the NR assays it is possible to observe that no effect on the membrane integrity occurred by the exposition to extracts, except in the phenol group (almost $100 \%$ reduction), as already reported $^{4,34}$ (Figure $3 b$ ).

The crystal violet intercalate to DNA and correlates to the cell number. Despite the slightly more CV intensity for $5 \%$ Sr-HA group $(\mathrm{p}<0.05,30 \%)$, no other significant difference was observed. In resume, this data indicates no effect of $\mathrm{Sr}-\mathrm{HA}$ extracts on cell viability. Also, phenol reduced $70 \%$ the number of adhered cells $(\mathrm{p}<0.05)$.

It is well known that different HA can be synthesized by substituting calcium, phosphate or hydroxyl groups resulting in biomaterials with different biological and chemical properties. Lima et al. ${ }^{4}$ assessed the number of viable Balb/c 3T3 fibroblasts (through an hemocytometer) after exposure to several metal modified apatites extracts for 24 hours as follows: $\mathrm{Ca}_{95} \mathrm{M}_{05}\left(\mathrm{PO}_{4}\right)_{6}(\mathrm{OH})_{2}(\mathrm{M}=\mathrm{Fe}, \mathrm{Zn}$, $\mathrm{Cu}, \mathrm{Co}, \mathrm{Sr}, \mathrm{Pb})$ and $\mathrm{Ca}_{10}\left(\mathrm{VO}_{4}\right)_{6}(\mathrm{OH})_{2}$. Sr-HA did not present any toxicity while phenol killed $82 \%$ of the cells. It was observed an increase of $70 \%$ and $20 \%$ in the number of cells exposed to the extracts of Fe-HA and Sr-HA, respectively. This study showed that cells response is dependent on the metal that substitutes calcium or phosphate ions in the crystal lattice of HA, and that $0.5 \%$ Sr-HA did not affect cell viability.

In general, the assays mainly used to evaluate cell responses on bioceramics are the XTT (reduced in soluble formazan compounds) and the MTT (reduced in insoluble formazan compounds), which are based on similar principles. Therefore, to the best of our knowledge, the literature is poor regarding NR uptake and CVDE assays to compare with the results of the Sr-modified apatites synthesized herein.

Cytotoxicity is a challenging process to analyze, as there are several ways to activate cellular disruption. In addition, all of these assays have their disadvantages that must be taken into consideration when analyzing the obtained data ${ }^{29,35}$. For instance, metabolic impairment assays such as MTT and XTT can be biased by occasional

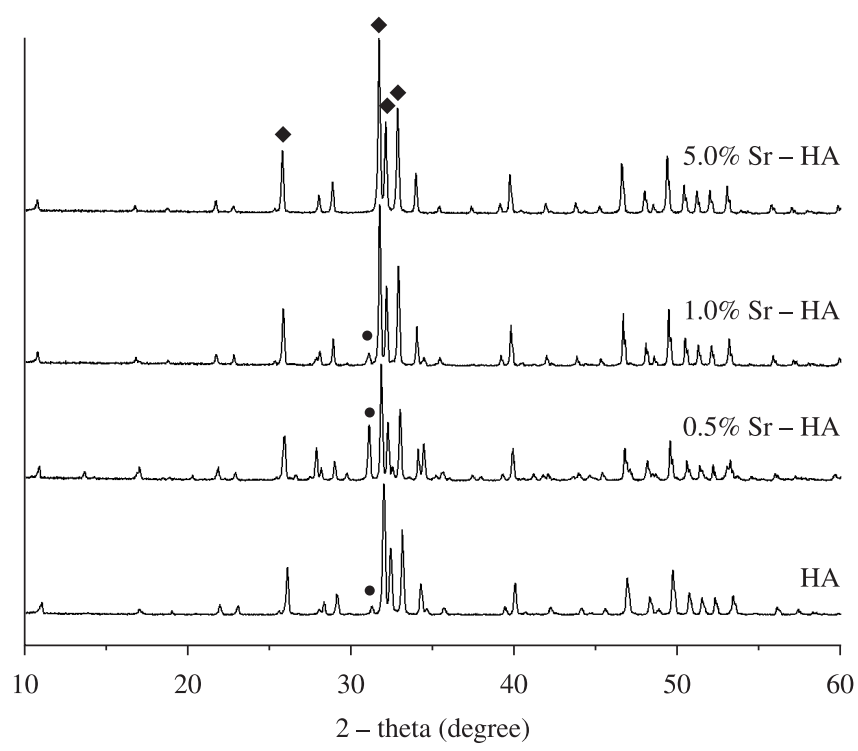

Figure 1. XRD patterns of pure and strontium-doped hydroxyapatites $(\bullet-\beta-$ TCP and $\bullet-\mathrm{HA})$.

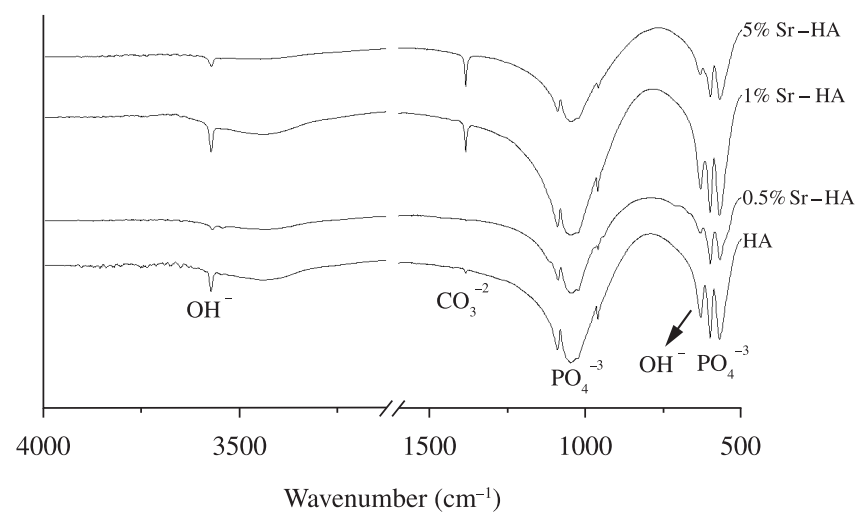

Figure 2. FTIR spectrum of pure HA and strontium-doped hydroxyapatites at different concentrations. 


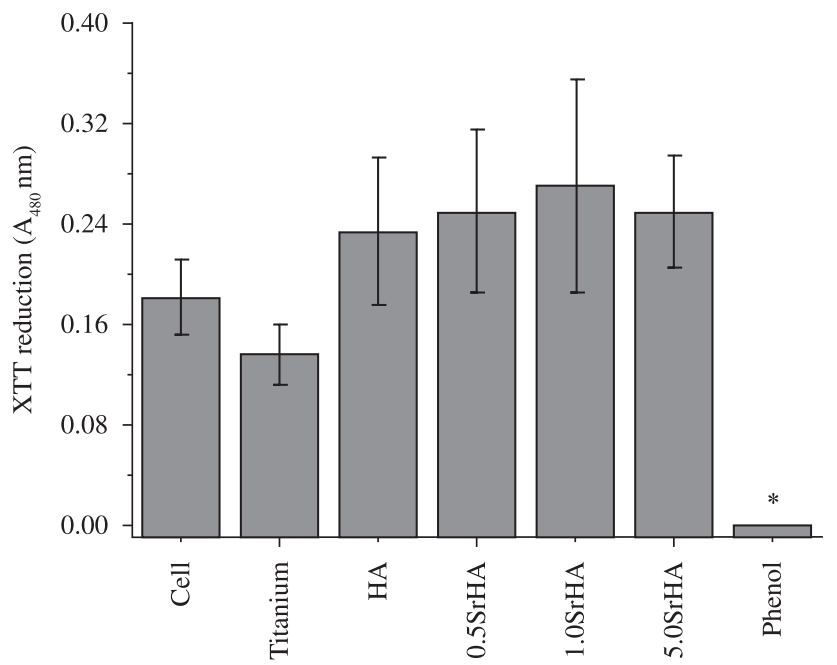

(a)

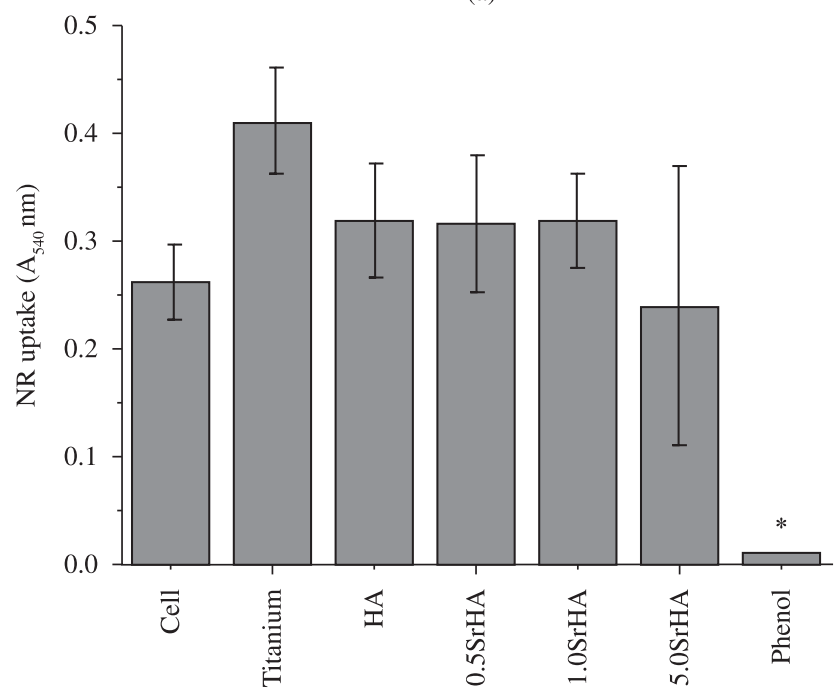

(b)

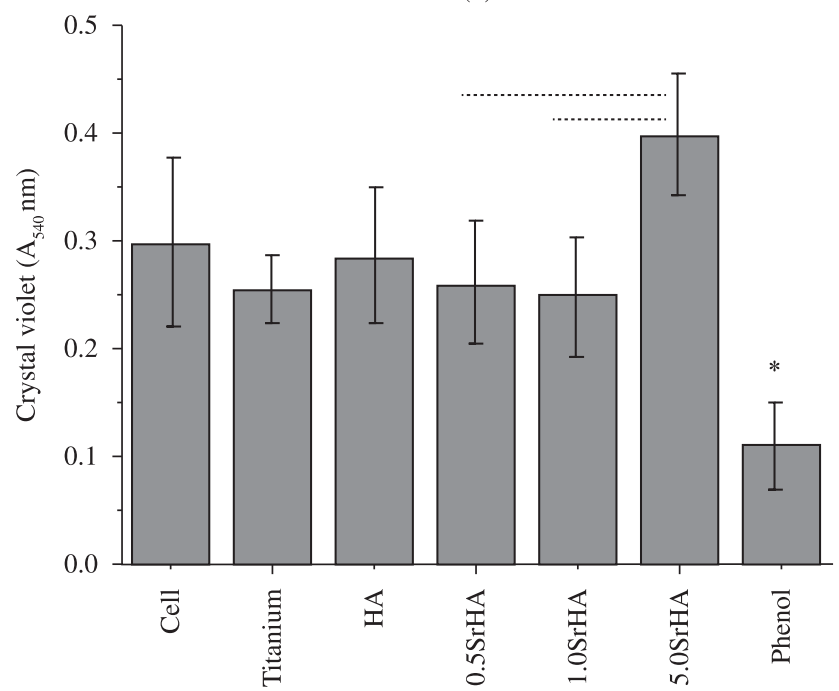

(c)

Figure 3. Cytotoxicity assay for pure HA and strontium-doped hydroxyapatites at different concentrations on mouse osteoblasts: a) XTT reduction; b) neutral red uptake; and c) crystal violet dye elution. The bars in the figure represent the standard deviation of means. Phenol group was statistically different from all samples tested in the three assays $(*, p<0.05) .(--)$ indicate a statistical difference between the samples $(\mathrm{p}<0.05)$. bacterial contamination, which can overestimate cell viability ${ }^{36}$; in contrast, some reducing agents and respiratory chain inhibitors of mitochondrial MTT reduction could underestimate cell viablity ${ }^{29}$. An increase in NR uptake by lysosomal swelling agents such as weakly basic substances ${ }^{37}$ could lead to an underestimation of cytotoxicity and $\mathrm{CV}$ dye can also stain dead cells due to its non-specificity in binding to $\mathrm{DNA}^{29}$. Concerning the $\mathrm{CV}$ test result, a considerable cell number was observed in the phenol group. However, those cells are in a death process since no metabolic activity was detected and CV also dyes dead cells that are still attached to the plate. This reinforces the necessity to evaluate more than one aspect of cell survival and integrity before attesting a biomaterial cytocompatibility. Likewise, biomaterials may affect diverse aspects points of cell viability.

Taken together, our results showed that incorporation of strontium in the hydroxyapatite, despite the potential increase in the Sr-HA solubility, did not affect the viability of murine osteoblasts, since no significant effect was observed in the metabolic activity, cell membrane integrity and DNA contend.

\section{Conclusion}

Granular hydroxyapatite containing from 0 to $5 \mathrm{~mol}$. (\%) of $\mathrm{Sr}$ was successfully produced and presented no cytotoxicity. The strontium incorporated in the HA crystal resulted in a solid solution with a minor phase $(\beta-T C P)$ identified by XRD, except for $\mathrm{Sr}=5 \mathrm{~mol}$. $(\%)$. Further studies are required to evaluate the potential benefits of Sr-HA as a bone substitute biomaterial and its effects in osteoporosis treatment.

\section{Acknowledgements}

We wish to thank FAPERJ, FINEP, MS/DECIT, CAPES and CNPq for financial support and NUCAT/UFRJ for XRF analysis.

\section{References}

1. Dorozhkin SV. Calcium orthophosphates. Journal of Materials Science: Materials in Medicine. 2007; 42(4):1061-1095.

2. Vallet-Regi M and Gonzalez-Calbet JM. Calcium phosphates as substitution of bone tissues. Progress in Solid State Chemistry. 2004; 32(1-2):1-31. http://dx.doi.org/10.1016/j.progsolidstchem.2004.07.001

3. Calasans-Maia MD, Rossi AM, Dias EP, Santos SRA, Áscoli F and Granjeiro J.M. Stimulatory effect on osseous repair of zinc-substituted hydroxyapatite: histological study in rabbit's tibia. Key Engineering Materials. 2008; 20(2):1269-1272. http://dx.doi.org/10.4028/www. scientific.net/KEM.361-363.1269

4. Lima IR, Santos SRA, Santiago DL, Rossi AM and Granjeiro JM. Cytotoxicity analysis of apatites modified with divalent metals. Key Engineering Materials. 2008; 20(2):1135-1138. http://dx.doi. org/10.4028/www.scientific.net/KEM.361-363.1135

5. Wopenka B and Pasteris JD. A mineral perspective on the apatite in bone. Materials Science and Engineering C. 2005; 25(2):131-143. http://dx.doi. org/10.1016/j.msec.2005.01.008

6. Ingham E and Fisher J. The role of macrophages in osteolysis of total joint replacement. Biomaterials. 2005; 26(11):1271-1286. PMid:15475057. http://dx.doi.org/10.1016/j.biomaterials.2004.04.035

7. Verberckmoes SC, Behets GJ, Oste L, Bervoets AR, Lamberts LV, Drakopoulos $\mathrm{M}$ et al. Effects of strontium on the physicochemical characteristics of hydroxyapatite. Calcified Tissue International. 2004; 75(5):405-415. PMid:15592797. http://dx.doi.org/10.1007/s00223-004-0260-4

8. Marie PJ, Garba MT, Hott M and Miravet L. Effect of low doses of stable strontium on bone metabolism in rats. Mineral Electrolyte Metabolism. 1985; 11(1):5-13. PMid:3974537.

9. Grympas MD, Hamilton E, Cheung R, Tsouderos Y, Deloffre P, Hott $\mathrm{M}$ et al. Strontium increases vertebral bone volume in rats at a low dose that does not induce detectable mineralization defect. Bone. 1996; 18(3):253-259. http://dx.doi.org/10.1016/8756-3282(95)00484-X 
10. Marie PJ. Strontium as therapy for osteoporosis. Current Opinion in Pharmacology. 2005; 5:633-636. PMid:16183330. http://dx.doi. org/10.1016/j.coph.2005.05.005

11. Ni GX, Lu WW, Xu B, Chiu KY, Yang C, Li ZY et al. Interfacial behaviour of strontium-containing hydroxyapatite cement with cancellous and cortical bone. Biomaterials. 2006; 27(29):5127-5133. PMid:16781769. http://dx.doi.org/10.1016/j.biomaterials.2006.05.030

12. Xue-Yang L and De-Min C. Effects of strontium substituted hydroxyapatite of different porosities on osteoblasts in vitro. Journal of Oral Tissue Engineering. 2005; 2(2):66-75.

13. Fu YF, Chen DM and Zhang JZ. In vitro study on the cytotoxicity of strontium substituted hydroxyapatite. Shanghai Kou Qiang Yi Xue. 2002; 11(3):229-232. PMid:14983257.

14. Capuccini C, Torricelli P, Boanini E, Gazzano M, Giardino R and Bigi A. Interaction of Sr-doped hydroxyapatite nanocrystals with osteoclast and osteoblast-like cells. Journal of Biomedical Materials Research Part A. 2009; 89(3):594-600 PMid:18437694. http://dx.doi.org/10.1002/ jbm.a.31975

15. Weyermann J, Lochmann D and Zimmer A. A practical note on the use of cytotoxicity assays. International Journal of Pharmaceutics. 2005; 288:369-376. PMid:15620877. http://dx.doi.org/10.1016/j. ijpharm.2004.09.018

16. International Organization for Standardization - ISO. ISO 10993-5: Biological evaluation of medical devices. Geneva: ISO; 1999. part 5: Tests for cytotoxicity: In vitro methods.

17. International Organization for Standardization - ISO. ISO 10993-12: Biological evaluation of medical devices. Geneva: ISO; 1996. Part 12: Sample preparation and reference materials.

18. Scudiero DA, Shoemaker RH, Paull KD, Monks A, Tierney S, Nofziger $\mathrm{TH}$ et al. Evaluation of a soluble tetrazolium/formazan assay for cell growth and drug sensitivity in culture using human and other tumor cell lines. Cancer Research. 1988; 48(17):4827-4833. PMid:3409223.

19. Winckler J. Vital staining of lysossomes and other cell organelles of the rat with neutral red. Progress in Histochemistry and Cytochemistry. 1974; 6(3):1-91.

20. Kueng W, Silber E and Eppenberger U. Quantification of cells cultured on 96-well plates. Analytical Biochemistry. 1989; 182(1):16-19. http://dx.doi.org/10.1016/0003-2697(89)90710-0

21. Bigi A, Boanini E, Capuccini C and Gazzano M. Strontium-substituted hydroxyapatite nanocrystals. Inorganica Chimica Acta. 2007; 360(3):1009-1016. http://dx.doi.org/10.1016/j.ica.2006.07.074

22. Kim HW, Koh YH, Kong YM, Kang JG and Kim HE. Strontium substituted calcium phosphate biphasic ceramics obtained by a powder precipitation method. Journal of Materials Science: Materials in Medicine. 2004; 15(10):1129-1134. PMid:15516874. http://dx.doi. org/10.1023/B:JMSM.0000046395.76435.60

23. Gibson IR, Rehman I, Best SM and Bonfield W. Characterization of the transformation from calcium-deficient apatite to $\beta$-tricalcium phosphate. Journal of Materials Science: Materials in Medicine. 2000; 11(12):799-804. PMid:15348063. http://dx.doi.org/10.1023/A:1008905613182

24. Dagang G, Kewei X, Xiaoyun Z and Yong H. Development of a strontium-containing hydroxyapatite bone cement. Biomaterials.
2005; 26 (19) 4073-4083. PMid:15664634. http://dx.doi.org/10.1016/j. biomaterials.2004.10.032

25. Fanovich MA and Porto Lopez JM. Influence of temperature and additives on the microstructure and sintering behaviour of hydroxyapatites with different $\mathrm{Ca} / \mathrm{P}$ ratios. Journal of Materials Science: Materials in Medicine. 1998; 9(1):53-60. PMid:15348702. http://dx.doi.org/10.1023/A:1008834712212

26. Christoffersen J, Christoffersen MR, Kolthoff $\mathrm{N}$ and Barenholdt O. Effects of strontium Ions on Growth and Dissolution of Hydroxyapatite and on Bone Mineral Detection. Bone. 1997; 20(1):47-54. http://dx.doi. org/10.1016/S8756-3282(96)00316-X

27. Zhang W, Shen Y, Pan H, Lin K, Liu X, Darvell BW et al. Effects of strontium in modified biomaterials. Acta Biomaterialia. 2011; 7:800-808. PMid:20826233. http://dx.doi.org/10.1016/j.actbio.2010.08.031

28. Landi E, Tampieri A, Celotti G, Vichi and Sandri M. Influence of synthesis and sintering parameters on the characteristics of carbonate apatite. Biomaterials. 2004; 25(10):1763-1770. PMid:14738839. http://dx.doi. org/10.1016/j.biomaterials.2003.08.026

29. Chiba K, Kawakami K and Tohyama K. Simultaneous evaluation of cell viability by neutral red, MTT and crystal violet staining assays of the same cells. Toxicology in Vitro. 1998; 12(3):251-258. http://dx.doi. org/10.1016/S0887-2333(97)00107-0

30. De-Deus G, Canabarro A, Alves G, Linhares A, Senne MI and Granjeiro JM. Optimal cytocompatibility of a bioceramic nanoparticulate cement in primary human mesenchymal cells. Journal of Endodontics. 2009; 35(10):1387-1390. PMid:19801236. http://dx.doi.org/10.1016/j.joen.2009.06.022

31. Capuccini C, Torricelli P, Sima F, Boanini E, Ristoscu C, Bracci B et al. Strontium-substituted hydroxyapatite coatings synthesized by pulsed-laser deposition: In vitro osteoblast and osteoclast response. Acta Biomaterialia. 2008; 4(6):1885-1893. PMid:18554996. http://dx.doi. org/10.1016/j.actbio.2008.05.005

32. Yuan-Fei F and De-Min C. Influence of $\mathrm{Sr}^{2+}$ on strontium substituted hydroxyapatite's (Sr-HA) cytotoxicity. Journal of Oral Tissue Engineering. 2005; 2:76-80.

33. Weichang X, Moore JL, Hosick HL, Bose S, Bandyopadhyay A, Lu WW et al. Osteoprecursor cell response to strontium-containing hydroxyapatite ceramics. Journal of Biomedical Materials Research Part A. 2006; 7(4):804-814.

34. Takamori ER, Figueira EA, Taga R, Sogayar MC and Granjeiro JM. Evaluation of the Cytocompatibility of Mixed Bovine Bone. Brazilian Dental Journal. 2007; 18(3):179-184. PMid:18176706. http://dx.doi. org/10.1590/S0103-64402007000300001

35. Murray PE, Godoy CG and Godoy FG. How is the biocompatibility of dental biomaterials evaluated? Medicina Oral, Patología Oral y Cirurgía Bucal. 2007; 12(E2):258-266.

36. Ciapetti G, Granchi D, Verri E, Savarino L, Cavedagna D and Pizzoferrato, A. Application of a combination of neutral red and amino Black staining for rapid, reliable cytotoxicity testing of biomaterials. Biomaterials. 1996; 17(13):1259-1264. http://dx.doi.org/10.1016/0142-9612(96)88670-4

37. Ohkuma S and Poole B. Cytoplasmic vacuolation of mouse peritoneal macrophages and the uptake into lysosomes of weakly basic substances. Journal of Cell Biology. 1981; 90(3):656-664. PMid:7287819. http://dx.doi.org/10.1083/jcb.90.3.656 